\title{
WestVirginiaUniversity
}

THE RESEARCH REPOSITORY @ WVU

West Virginia Agricultural and Forestry Experiment

Davis College of Agriculture, Natural Resources

Station Bulletins

And Design

$1-1-1955$

\section{Drugs for controlling coccidiosis in chickens}

\author{
J. O. Heishman \\ C.J. Cunningham
}

T. B. Clark

Follow this and additional works at: https://researchrepository.wvu.edu/ wv_agricultural_and_forestry_experiment_station_bulletins

\section{Digital Commons Citation}

Heishman, J. O.; Cunningham, C. J.; and Clark, T. B., "Drugs for controlling coccidiosis in chickens" (1955). West Virginia Agricultural and Forestry Experiment Station Bulletins. 376.

https://researchrepository.wvu.edu/wv_agricultural_and_forestry_experiment_station_bulletins/369 @ WVU. It has been accepted for inclusion in West Virginia Agricultural and Forestry Experiment Station Bulletins by an authorized administrator of The Research Repository @ WVU. For more information, please contact ian.harmon@mail.wvu.edu. 


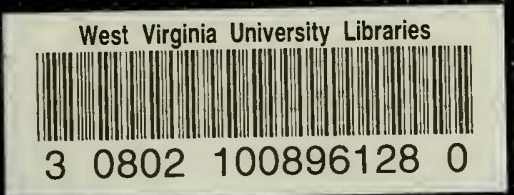


Digitized by the Internet Archive in 2010 with funding from

Lyrasis Members and Sloan Foundation 


\section{BULLETIN 376}

June 1955

\section{Drugs for Controlling Coccidiosis in Chickens}




\section{ACKNOWLEDGMENT}

The sulfaquinoxaline was provided by Merck \& Company; and Lederle Laboratories Division, American Cyanamid Company, provided the nitrophenide "Megasul" for this study.

\section{AUTHORS}

Authors of Drugs for Controlling Coccidiosis in Chickens are J. O. Heishman, Associate Animal Pathologist; C. J. Cunningham, Associate Animal Husbandman, in charge of Reymann Memorial Experimental Farms Substation; and T. B. Clark, Associate Poultry Husbandman and Associate Professor of Poultry Husbandry.

WEST VirginIA UNIVERSITY Agricultural Experiment Station

College of Agriculture, Forestry, and Home Economics H. R. VARNEY, DIRECTOR 


\section{Drugs for Controlling Coccidiosis in Chickens}

\section{Introduction}

J. O. Heishman, C. J. Cunningham, and T. B. Clark

THIS bulletin reports results obtained from an experiment conducted to study the effects of feeding sulfaquinoxaline and nitrophenide. The two coccidiostatic drugs were fed continuously to broilers and compared with non-medicated controls. An experiment is also reviewed which dealt with the effects from the continuous feeding of sulfaquinoxaline during the growing period on the performance of pullets in the laying period.

Sanitation alone proved ineffective in controlling coccidiosis. The feeding of coccidiostatic drugs was recognized as the most practical control method. Satisfactory results from drugs seemed to depend on regulating the size of the dose of coccidia so that the flock could gradually develop immunity along with low mortality and no set-back in growth.

When these experiments were started in 1950, certain sulfa drugs had been reported to be satisfactory when fed intermittently. To feed these drugs continuously required less attention, and results on the possible use of sulfaquinoxaline fed at a low level continuously in the mash were reported by Grumbles, Delaplane, and Higgins (1948). The following year, Lucas, Tomhave, and Seeger (1949) reported that nitrophenide "Megasul" was also effective in controlling coccidiosis. Since then numerous investigators have measured the effects of various drugs fed continuously for the control of coccidiosis.

The feeding trials reported here were initiated to study (1) the effect of drugs on mortality; (2) the effect of the drugs on uniformity of growth and feed consumption; (3) the effect of the continuous use of these drugs in conjunction with deep, built-up litter; (4) the possibility of using less than 0.0125 per cent $(1 / 4$-pound per ton); (5) the value of such drugs when coccidiosis is not severe; and (6) the effect on the subsequent performance of pullets.

The results for the last objective (6) have been reported by Bletner, Clark, and Olson (1954). White Leghorns were used in studying the effect of feeding a low level, 0.0125 per cent of sulfaquinoxaline continuously during the growing period on the laying house performance 
of pullets. The experiment was conducted with replicated lots in two different years. In the second year a mild outbreak of coccidiosis appeared in four of the six non-medicated pens. At ten weeks of age in both years the pullets fed the medicated feed were slightly heavier than the non-medicated controls. At laying age the differences had disappeared. Egg production and laying house mortality were similar for the non-medicated and medicated lots. These results indicated that the use of sulfaquinoxaline to control coccidiosis during the growing period had no apparent detrimental effect on the laying house performance of the pullets.

\section{Plan of Experiment}

The studies herein reported were conducted in a recently constructed cinder block building described in West Virginia University Agricultural Experiment Station Circular 85, (1951). The building is located on a West Virginia University Substation Farm at Wardensville. The building has a central feed room. For these studies the house was divided into eight pens, each about 22 by 31 feet, with a capacity as given in Table 1. A central alley running the long way provides access to the pens. The house is heated by forced hot air and is designed so that it is uniformly heated and lighted.

Table 1. Plan of Experiment for Three Trials

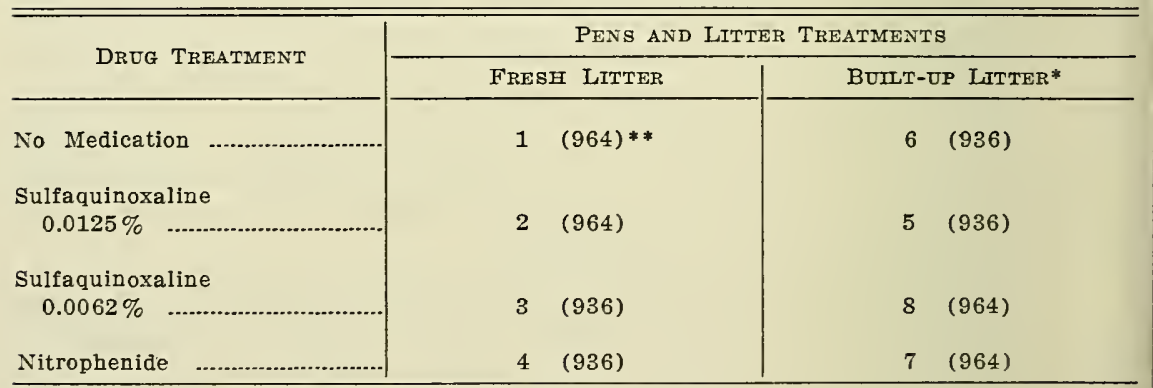

* Built-up litter was used in Trials 2 and 3 .

**Numbers in parenthesis give capacity of pens at $3 / 4$ sq. ft. of floor space per bird.

Three broods of chicks were used in the first series of trials in order to cover climatic conditions during different seasons of the year. The chicks were straight-run New Hampshires obtained from U. S. Pullorum clean hatcheries in West Virginia. They were vaccinated against Newcastle disease. The wing-web method of vaccination was used for the first brood and the intranasal vaccine was used on the other broods. 
Immediately following delivery, the chicks in each box were divided as equally as possible among the eight pens in the broiler house. The chicks were thus allotted at random to the pens at the rate of one chick to each $3 / 4$ of a square foot of floor space. Pairs of pens were allotted to each treatment as shown in Table 1.

Approximately $21 / 2$ inches of fresh sawdust was placed on the floor of each pen before the first brood of chicks was put in the house. Follow. ing the first brood, the litter in four pens in one end of the house was removed and replaced by clean sawdust before starting the second brood. The litter was not removed from the four pens in the other end of the house nor was fresh litter added to these pens during the course of the experiment. The only attention the litter in this end of the house received between the next broods was to remove a small quantity of wet material around water fountains and a limited amount of caked material. The litter was not stirred but merely leveled before each brood of chicks was started.

The chicks in each of the three broods were fed a uniform ration consisting of a concentrate, purchased from a commercial feed company, and ground home-grown grains. The concentrate and grains were mixed and the medication added at the farm.

The broilers were weighed individually at twelve weeks of age. Records were maintained of the feed consumed on a pen basis. The hover and room temperatures and the relative humidity were recorded daily.

The treatments for the first three trials are given in Table 1. Pens 1 and 6 served as controls with no drugs being fed. Drugs were fed continuously to the other pens.

A post-mortem examination was made of all chickens that died during the experiment except very young chicks and chickens that were not discovered until they were badly decomposed. In carrying out the post-mortem examination, special attention was given to determining if coccidiosis was the cause of death. Cases obviously due to coccidiosis were recorded as such, and cecal and intestinal contents from questionable cases were submitted to a microscopic examination. No attempt was made to identify the various species of coccidia encountered.

\section{Results and Discussion MORTALITY}

From previous experience, a mortality of 10 to 15 per cent directly traceable to infection with coccidia was expected to occur among young chickens that were not receiving any drug treatment for the disease. However, as shown in Table 2, a mortality from coccidiosis of 1.16 per 
Table 2. Mortality from Coccidiosis and All Causes (Per Cent)

\begin{tabular}{|c|c|c|c|c|c|c|c|c|}
\hline \multirow[b]{2}{*}{ TREATMENT } & \multicolumn{2}{|c|}{ Trial 1} & \multicolumn{2}{|c|}{ Trial 2.} & \multicolumn{2}{|c|}{ TRLAL 3} & \multicolumn{2}{|c|}{ ALL TRIALS } \\
\hline & $\begin{array}{l}\text { CoccI- } \\
\text { DIOSIS }\end{array}$ & $\begin{array}{c}\text { ALL } \\
\text { CAUSES }\end{array}$ & $\begin{array}{l}\text { Cocci- } \\
\text { DIosis }\end{array}$ & $\begin{array}{c}\text { ALL } \\
\text { CAUSES } \\
\end{array}$ & $\begin{array}{l}\text { CoccI- } \\
\text { DIosis }\end{array}$ & $\begin{array}{c}\text { ALL } \\
\text { CAUSES } \\
\end{array}$ & $\begin{array}{l}\text { CoccI- } \\
\text { Drosis }\end{array}$ & $\begin{array}{c}\text { ALL } \\
\text { CAUSES }\end{array}$ \\
\hline No Medication & 1.47 & 6.36 & 0.58 & 4.61 & 1.42 & 7.38 & 1.16 & 6.12 \\
\hline $\begin{array}{c}\text { Sulfaquinoxaline } \\
0.0125 \%\end{array}$ & 0.05 & 2.78 & 0.31 & 3.99 & 0.21 & 5.96 & 0.23 & 4.24 \\
\hline $\begin{array}{l}\text { Sulfaquinoxaline } \\
0.0062 \%\end{array}$ & 0.68 & 4.99 & 0.48 & 6.35 & 0.05 & 4.62 & 0.41 & 5.32 \\
\hline $\begin{array}{c}\text { Nitrophenide } \\
0.0125 \%\end{array}$ & 0.31 & 6.24 & 0.16 & 5.44 & 0.21 & 7.20 & 0.23 & 6.29 \\
\hline
\end{tabular}

cent for all trials in the control pens was much lower than anticipated. The lack of a real outbreak of coccidiosis, even in the control pens, did not afford an opportunity to show striking differences in mortality between the chickens receiving medication and those which were not. The difference in mortality that did exist indicated that the drugs in the feed had a definite inhibiting effect on the development of coccidiosis. It was also noted that the 0.0125 per cent levels of sulfaquinoxaline and "Megasul" were equally effective in preventing mortality resulting from coccidiosis and were superior in this respect to the 0.0062 per cent level of sulfaquinoxaline. Recent results suggest that with such a low level of sulfaquinoxaline a severe outbreak of coccidiosis likely would have resulted in a heavy mortality. The average mortality from all causes was slightly less for the pens receiving the 0.0125 per cent level of sulfaquinoxaline than for the other treatments.

\section{AVERAGE BODY WEIGHT; AVERAGE POUNDS OF FEED UTILIZED}

The results reported in Table 3 show there were no marked differences between treatments in average body weight of both sexes to twelve weeks of age. The small differences are consistently in favor of the lots fed medicated feeds. Similar results were obtained for the average pounds of feed consumed per pound of broiler produced, as shown in Table 4. In both the average body weight and the pounds of feed utilized, the 0.0125 per cent level of sulfaquinoxaline and "Megasul" produced slightly better results than did the lower level of sulfaquinoxaline.

\section{COMPARISON OF FRESH AND BUILT-UP LITTER}

The continuous feeding of these drugs in conjunction with deep, built-up litter was being questioned when this study was initiated. 
Table 3. Average Body Weight of Both Sexes at 12 Weeks of Age

\begin{tabular}{|c|c|c|c|c|}
\hline \multirow{2}{*}{ TREATMENT } & \multicolumn{4}{|c|}{ BODY WEIGHT (POUNDS) } \\
\hline & Trial 1 & Trial 2 & Trial 3 & ALL TRIALS \\
\hline No Medication ... & 2.82 & 3.13 & 2.79 & 2.91 \\
\hline $\begin{array}{l}\text { Sulfaquinoxaline } \\
0.0125 \%\end{array}$ & 3.01 & 3.21 & 2.88 & 3.03 \\
\hline $\begin{array}{l}\text { Sulfaquinoxaline } \\
\quad 0.0062 \%\end{array}$ & 2.87 & 3.15 & 2.86 & 2.96 \\
\hline $\begin{array}{c}\text { Nitrophenide } \\
0.0125 \%\end{array}$ & 2.87 & 3.18 & 2.93 & 2.99 \\
\hline
\end{tabular}

Table 4. Average Pounds of Feed Utilized per Pound of Body Weight for Both Sexes to 12 Weeks of Age

\begin{tabular}{|c|c|c|c|c|}
\hline \multirow{2}{*}{ TREATMENT } & \multicolumn{4}{|c|}{ FEed UtILIZED (POUNDS) } \\
\hline & Trial 1 & TRIAL 2 & TRIAL 3 & ALL TRIALS \\
\hline No Medication ... & 3.61 & 3.50 & 3.62 & 3.58 \\
\hline $\begin{array}{c}\text { Sulfaquinoxaline } \\
0.0125 \%\end{array}$ & 3.34 & 3.44 & 3.61 & 3.46 \\
\hline $\begin{array}{l}\text { Sulfaquinoxallne } \\
\quad 0.0062 \%\end{array}$ & 3.56 & 3.50 & 3.58 & 3.55 \\
\hline $\begin{array}{c}\text { Nitrophenide } \\
0.0125 \%\end{array}$ & 3.54 & 3.43 & 3.56 & 3.51 \\
\hline
\end{tabular}

Some broiler growers believed at that time that an accumulation of the drugs in re-used litter might have toxic effects on the broilers resulting in uneven growth and increased morbidity. The data are presented in Tables 5 and 6 so that the fresh and built-up litter may be compared with respect to these conditions.

A study of the results reported in these tables show that the average mortality from all causes for each of the litters was similar. Also, the averages for body weight and feed utilized were nearly alike for both kinds of litter. It is clear that if there was any build-up of the drugs in the re-used litter, the accumulation had no apparent detrimental effects on the chicks. In fact, it appears that growing chickens can tolerate considerably more of the drugs than might have been ingested in these trials.

While this study was in progress some results were obtained at this Station on the upper limits of sulfaquinoxaline feeding. Bletner and coworkers (1953) fed as much as 0.05 per cent ( 1 pound per ton) in the 
Table 5. Comparison of Mortality on Fresh and Built-up Litters FOR THREe Trials

\begin{tabular}{|c|c|c|c|c|}
\hline \multirow{2}{*}{ TREATMENT } & \multicolumn{2}{|c|}{ Fresh Litter } & \multicolumn{2}{|c|}{ BUILT-UP LITTER } \\
\hline & Coccidiosis & ALL CAUSES & Coccidiosis & ALL CaUses \\
\hline & Per cent & Per cent & Per cent & Per cent \\
\hline No Medication ... & 1.50 & 6.26 & 0.83 & 5.98 \\
\hline $\begin{array}{l}\text { Sulfaquinoxaline } \\
0.0125 \%\end{array}$ & 0.35 & 4.12 & 0.04 & 4.37 \\
\hline $\begin{array}{c}\text { Sulfaquinoxaline } \\
0.0062 \%\end{array}$ & 0.52 & 5.48 & 0.29 & 5.15 \\
\hline $\begin{array}{c}\text { Nitrophenide } \\
0.0125 \%\end{array}$ & 0.28 & 6.03 & 0.17 & 6.54 \\
\hline Average ..... & 0.66 & 5.46 & 0.33 & 5.52 \\
\hline
\end{tabular}

Table 6. Average Body Weight and Feed Utilized on Different LitTers for Three Trials

\begin{tabular}{|c|c|c|c|c|}
\hline \multirow{2}{*}{ TREATMENT } & \multicolumn{2}{|c|}{ FRESH LITTER } & \multicolumn{2}{|c|}{ BUILT-UP LITTER } \\
\hline & BODY WEIGHT & Feed Utilized & BODY WEIGHT & FEed Utillized \\
\hline & Pounds & Pounds & Pounds & Pounds \\
\hline No Medication & 2.90 & 3.62 & 2.93 & 3.53 \\
\hline $\begin{array}{c}\text { Sulfaquinoxaline } \\
0.0125 \%\end{array}$ & 3.08 & 3.40 & 2.98 & 3.53 \\
\hline $\begin{array}{c}\text { Sulfaquinoxaline } \\
0.0062 \%\end{array}$ & 2.99 & 3.53 & 2.93 & 3.56 \\
\hline $\begin{array}{c}\text { Nitrophenide } \\
0.0125 \%\end{array}$ & 3.01 & 3.56 & 2.97 & 3.46 \\
\hline Average & 2.99 & 3.52 & 2.95 & 3.52 \\
\hline
\end{tabular}

mash continuously to chicks in batteries starting at two weeks of age and continuing for four weeks. This is four times the amount of that used in the experiments reported here. In simplified rations this high level gave evidence of toxic results. However, in commercial types of broiler rations there appeared to be no detrimental effects; at least no set-back in growth occurred.

\section{NET RETURNS}

A question which should be answered regarding any practice under consideration for recommendation to broiler producers is-will it be practicable and result in more profit? Results which help to answer this 
question, in connection with the continuous feeding of drugs for the control of coccidiosis, are presented in Table 7 . These results show that in each case the total net returns were greater from the birds receiving medicated feed than from the non-medicated controls. In other words, the calculations in the table show that even in the absence of a severe outbreak of coccidiosis, the increased returns from the birds receiving medication more than paid for the cost of the drugs.

Table 7. Comparison of Treatment According to Costs and Returns

\begin{tabular}{|c|c|c|c|c|c|c|}
\hline TREATMENT & TRIAL & $\begin{array}{c}\text { FEED } \\
\text { CoNsUMEd }\end{array}$ & $\begin{array}{c}\text { Cost OF } \\
\text { FEED AND } \\
\text { MEDICATION }\end{array}$ & $\mid \begin{array}{c}\text { CHICKENS } \\
\text { SOLD AT } \\
12 \text { WEEKS }\end{array}$ & $\begin{array}{c}\text { GRoss } \\
\text { RETURNS* }\end{array}$ & $\begin{array}{c}\text { Net } \\
\text { RETURNS** }\end{array}$ \\
\hline $\begin{array}{c}\text { No Medication } \\
\text { (Controls) } \\
\text { Treatment } \\
\text { Totals }\end{array}$ & $\begin{array}{l}1 \\
2 \\
3\end{array}$ & $\begin{array}{l}\text { Pounds } \\
18740 \\
20079 \\
18669 \\
57488\end{array}$ & $\begin{array}{c}\text { Dollars } \\
828.96 \\
903.05 \\
874.78 \\
\\
2606.79\end{array}$ & $\begin{array}{c}\text { Pounds } \\
5003 \\
5591 \\
4911 \\
\\
15505\end{array}$ & $\begin{array}{c}\text { Dollars } \\
1250.75 \\
1551.50 \\
1522.41 \\
\\
4324.66\end{array}$ & $\begin{array}{r}\text { Dollars } \\
421.79 \\
648.45 \\
6 \pm 7.63 \\
\\
1717.87\end{array}$ \\
\hline $\begin{array}{l}\text { Sulfaquinoxaline } \\
0.0125 \% \\
\text { Treatment } \\
\text { Totals }\end{array}$ & $\begin{array}{l}1 \\
2 \\
3\end{array}$ & $\begin{array}{l}19342 \\
20598 \\
19516 \\
59456\end{array}$ & $\begin{array}{r}884.61 \\
957.29 \\
941.25 \\
\\
2783.15\end{array}$ & $\begin{array}{r}5554 \\
5855 \\
5190 \\
\\
16599\end{array}$ & $\begin{array}{l}1388.50 \\
1624.76 \\
1608.90 \\
4622.16\end{array}$ & $\begin{array}{r}503.89 \\
667.47 \\
667.65 \\
1839.01\end{array}$ \\
\hline $\begin{array}{l}\text { Sulfaquinoxaline } \\
0.0062 \% \\
\text { Treatment } \\
\text { Totals }\end{array}$ & $\begin{array}{l}1 \\
2 \\
3\end{array}$ & $\begin{array}{l}18931 \\
20019 \\
19143 \\
58093\end{array}$ & $\begin{array}{r}847.11 \\
915.37 \\
908.96 \\
\\
2671.44\end{array}$ & $\begin{array}{r}5174 \\
5509 \\
5223 \\
\\
15906\end{array}$ & $\begin{array}{l}1293.50 \\
1528.75 \\
1619.13 \\
\\
4441.38\end{array}$ & $\begin{array}{r}446.39 \\
613.38 \\
710.17 \\
1769.94\end{array}$ \\
\hline $\begin{array}{c}\text { Nitrophenide } \\
0.0125 \% \\
\text { Treatment } \\
\text { Totals } \\
\text {......... }\end{array}$ & $\begin{array}{l}1 \\
2 \\
3\end{array}$ & $\begin{array}{l}19071 \\
20035 \\
19256 \\
\\
58362\end{array}$ & $\begin{array}{r}872.24 \\
930.66 \\
928.75 \\
\\
2731.65\end{array}$ & $\begin{array}{r}5177 \\
5646 \\
5176 \\
\\
15999\end{array}$ & $\begin{array}{l}1294.25 \\
1566.77 \\
1604.56 \\
\\
4465.58\end{array}$ & $\begin{array}{r}422.01 \\
636.11 \\
675.81 \\
\\
1733.93\end{array}$ \\
\hline
\end{tabular}

*Selling Price per pound: Trial 1, 25c; Trial 2, $27 \% / 4 c$; Trial 3, 31c.

**Net Returns-Gross returns less cost of feed and medication.

\section{COMPARISON OF LITTERS WITHOUT DRUGS}

During the time the data on the continuous feeding of drugs for the control of coccidiosis were being collected, a question was raised regarding the coccidiostatic value of deep built-up litter as compared with new litter. To obtain information on this problem, Trial 4 was conducted starting in May 1953. The litter was removed from half of the broiler house, the walls hosed down, floors scrubbed, and clean litter put down. Litter on which ten broods of chickens had been raised was left in the other half of the building. In other respects both ends of the house were treated alike. Medication for the control of coccidiosis was not administered to any of the chickens. 
Results of this trial are summarized in Tables 8 and 9. It will be noted that the mortality due to coccidiosis was very low on both fresh and built-up litter. However, the difference which did exist in mortality from coccidiosis and from all causes was in favor of the fresh litter. On the other hand, there was a slight advantage in favor of the built-up litter in average body weight and feed utilization. As shown in Table 9, the net returns from the chickens raised on the two types of litter were almost identical. Results of this trial indicate that built-up litter under these conditions has very little effect on mortality or morbidity due to coccidiosis as compared with fresh litter. However, in view of the fact that there was a very low incidence of coccidiosis on both types of litter, these results can not be considered conclusive.

Table 8. Comparison of Treatments-Trial 4

\begin{tabular}{|c|c|c|c|c|c|}
\hline \multirow{2}{*}{ TREATMENT } & \multirow{2}{*}{$\begin{array}{l}\text { BroILERS } \\
\text { FINISHED }\end{array}$} & \multirow{2}{*}{$\begin{array}{c}\text { AVERAGE } \\
\text { BODY WEIGHT }\end{array}$} & \multirow{2}{*}{$\begin{array}{c}\text { FEED } \\
\text { UTILIZED }\end{array}$} & \multicolumn{2}{|c|}{ MoRtality } \\
\hline & & & & Coccidrosis & ALL CAUSE:S \\
\hline & Number & Pounds & Pounds & Per cent & Per cent \\
\hline Fresh Litter ... & 3584 & 3.37 & 3.17 & 0.28 & 3.07 \\
\hline Built-up Litter & 3521 & 3.38 & 3.15 & 0.51 & 4.63 \\
\hline
\end{tabular}

Table 9. Cost and Returns on Fresh and Built-up Litters-Trial 4

\begin{tabular}{c|c|c|c|c|c}
\hline \hline \multirow{2}{*}{ Treatment } & \multicolumn{2}{|c|}{ Feed Consumed } & $\begin{array}{c}\text { Chickens } \\
\text { Sold AT } \\
12 \text { WeEks }\end{array}$ & $\begin{array}{c}\text { Gross } \\
\text { Returns* }\end{array}$ & $\begin{array}{c}\text { Net } \\
\text { Returns }\end{array}$ \\
\cline { 2 - 4 } & Pounds & Cost & Pounds & Dollars & Dollars \\
\cline { 2 - 5 } Fresh Litter & 38631 & 2576.19 & 12076 & 3864.32 & 1288.13 \\
Built-up Litler & 38653 & 2519.04 & 11906 & 3810.24 & 1291.20 \\
\hline
\end{tabular}

- Selling price per pound : $32 \mathrm{c}$.

\section{Summary and Conclusions}

At the time the investigation herein reported was considered, some broiler producers were of the opinion that drugs being recommended for the control of coccidiosis were either ineffective or toxic, thus causing uneven growth. The work was undertaken to obtain first-hand information regarding the effectiveness of these drugs under conditions of broiler management in West Virginia.

The investigation was conducted in a modern broiler house having a capacity of approximately eight thousand chicks. Data were collected on four broods which were spaced to cover the various seasons of the 
year. Two levels of sulfaquinoxaline, 0.0125 per cent and 0.0062 per cent, and one level of "Megasul," 0.0125 per cent, were fed continuously to the first three broods. The fourth brood did not receive medication, but half of the chicks were brooded on fresh litter and half on litter on which ten previous broods had been raised. Adequate control groups were maintained.

Although there was evidence of both cecal and intestinal coccidial infections during each trial, a severe outbreak of coccidiosis did not occur even in the control pens. This lack of a real outbreak of the diseases did not afford an opportunity to show a marked contrast in mortality, average body weight, and feed efficiency between the medicated and nonmedicated birds. However, the data obtained indicated that the 0.0125 per cent level of "Megasul" and the 0.0125 per cent level of sulfaquinoxaline had a definite beneficial effect on mortality, average body weight, and feed utilization. The combined effect was reflected in increased net income from the medicated birds. In addition, there was no indication of a toxic effect from the drugs as such or from an accumulation of the drugs in built-up litter.

\section{References}

Bletner, J. K., T. B. Clark, C. E. Weakley, Jr., and A. H. VanLandingham. 1953. The effect of sulfaquinoxaline in different ration formulations on growth and feed efficiency of coccidia-free chicks. Poultry Science 32:733-739.

Bletner, J. K., T. B. Clark and N. O. Olson. 1954. Sulfaquinoxaline preventative medication-Its effect on the subsequent laying performance of pullets. $\mathrm{W}$. Va. Univ. Agr. Exp. Sta. Bul. 363, Part 4. (Science Serves Your Farm), p. 7.

Clark, T. B. and C. J. Cunningham, 1951. The West Virginia Broiler House. W Va. Univ. Agr. Exp. Sta. Circ. No. 85.

Grumbles, L. C., J. P. Delaplane and T. C. Higgins. 1948. Sulfaquinoxaline in the control of Eimeria tenella and Eimeria necatrix in chickens on a commercial broiler farm. Science 107:196.

Lucas, William C., A. E. Tomhave, and Karl C. Seeger, 1949. The effect of nitrophenide, sulfaquinoxaline, sulfamethazine and sulfaguanidine in the control of cecal coccidiosis. Delaware Agri. Exp. Sta. Bul., 280. 


